Asian-Australasian Journal of Bioscience and Biotechnology ISSN 2414-1283 (Print) 2414-6293 (Online) www.ebupress.com/journal/aajbb

\title{
Article \\ Efficacy of vermicompost and biochar on the growth and yield of green cabbage
}

\author{
Nabila Hassan ${ }^{1}$, Abul Hasnat M Solaiman ${ }^{1 *}$, Anamul Arefin ${ }^{2}$, Rinita Islam ${ }^{1}$ and Sharika Hayder ${ }^{1}$ \\ ${ }^{1}$ Department of Horticulture, Sher-e-Bangla Agricultural University, Dhaka, Bangladesh \\ ${ }^{2}$ FabLab Fellow, FabLabSAU, Sher-e-Bangla Agricultural University, Dhaka, Bangladesh \\ *Corresponding author: Professor Dr. Abul Hasnat M Solaiman, Department of Horticulture, Sher-e-Bangla \\ Agricultural University, Dhaka, Bangladesh. E-mail: ahmsolaimanhort@ sau.edu.bd
}

Received: 20 June 2021/Accepted: 17 August 2021/ Published: 31 August 2021

\begin{abstract}
Organic production of Green Cabbage may ensure the nutritional status and food safety for the consumers, but maintaining the productivity and economic viability of inorganic production is almost impossible for farmers of Bangladesh. At this context, a study was carried out at the Horticulture farm of Shere-Bangla Agricultural University, Dhaka, Bangladesh during the period from October 2017 to March 2018 to evaluate the efficacy of vermicompost and biochar on agronomic properties and economic of cabbage. Four biochar treatments, ( $\mathrm{B}_{0}: 0 \mathrm{tha}^{-1}$ biochar, $\mathrm{B}_{1}: 2 \mathrm{t} \mathrm{ha}^{-1}, \mathrm{~B}_{2}: 6 \mathrm{t} \mathrm{ha}^{-1}$ and $\left.\mathrm{B}_{3}: 10 \mathrm{tha}^{-1}\right)$ and three vermicompost treatments $\left(\mathrm{Vc}_{0}: 0 \mathrm{tha} \mathrm{ha}^{-1}, \mathrm{Vc}_{1}: 4 \mathrm{tha}^{-1}\right.$ and $\left.\mathrm{Vc}_{2}: 8 \mathrm{tha}^{-1}\right)$ were selected. $\mathrm{B}_{0} \mathrm{Vc}_{0}$ was considered as control. The results revealed that maximum highest plant height, number of leaves plant ${ }^{-1}$, leaf length, leaf breadth and plant spread were obtained when the $\mathrm{B}_{3}$ was mixed withVc $\mathrm{c}_{2}$. But the thickness of head $(10.29 \mathrm{~cm})$, diameter of head $(16.66 \mathrm{~cm}), \%$ dry matter of cabbage $(14.93 \%)$, weight of cabbage head plant ${ }^{-1}(1370 \mathrm{~g})$ and yield of cabbage $\left(52.75 \mathrm{tha}^{-1}\right)$ were obtained from the treatment combination of $\mathrm{B}_{2} \mathrm{Vc}_{2}$. In terms of economic sustainability, the net return (Tk 523598) with highest BCR (3.70) was obtained from the treatment combination of $\mathrm{B}_{1} \mathrm{Vc}_{1}$. These results provide prove the effectiveness of biochar and vermicompost in sustainable Cabbage production. It also provides baseline guidelines for further investigation of choosing the appropriate combination of organic amendments based on crop requirement to maximize economic value.
\end{abstract}

Keywords: organic production; biochar; vermicompost; green cabbage; economic sustainability; safe food; Bangladesh

\section{Introduction}

Cabbage or 'Bhadha Kopi' (Brassica oleracea var. capitata L.), are one of the most popular and nutritionally rich vegetable in Bangladesh. Historically, recognized as a medicinal herb (Pavla and Pokluda, 2008), this member of Brassicaceae family has high water and fiber content. It is a rich source of vitamin A and vitamin C as well as some B vitamins (Adeniji et al., 2010; Hasan and Solaiman, 2012) and calcium. The antiinflammatory properties of Green Cabbage are attributed to the presence of glutamine, an amino acid (Caunii et al., 2010). Research has shown that cabbage has a number of anti-oxidative compounds that might be beneficial in the prevention of cancer (Kusznierewicz et al., 2008). This crop is widely cultivated and consumed in both fresh and processed market of Bangladesh. According to a report of BBS (2018), it ranks third in respect of production (207 thousand metric tons) and area (15783 hectors). But, the production of this crop requires heaving feeding at field stage to ascertain its high nutritional quality (Morem, 2006 and Semuli, 2005). It is an established fact that farmers of Bangladesh remarkably relay on chemical nutrients management improve the growth, yield as well as the nutritional composition of the produces. Nonetheless, it is essential to consider that use of excessive amount of inorganic fertilizers for crops is not good for health due to residual effects. In addition to that intensive use of agro-chemicals combined with poor disposal system, has raised concerns for both the contamination of surface water (Garg and Kaushik, 2003) and environment (Sinha et al., 2010). Beside 
the health and environmental implications of using synthetic fertilizers, smallholder farmers lack adequate financial resources to afford expensive fertilizers. Use of organic amendments by completely replacing inorganic agro-chemicals is the most plausible way to overcome this situation.

Not only organic fertilizer resolves the problems of agro-chemicals, it also increases the productivity of soil as well as crop quality and yield (Tindall, 2000). Organic amendments offer a two-way practice of saving the environment, namely- transformation of waste materials into valuable resources, soil nutrients (Anon, 2009) and improvement the soil health. They are slow but continuous and long-term supplier of soil nutrients. Besides high level of carbon and nitrogen; phosphorous, potassium, sulfur and a considerable number of other micronutrients is also present in organic manures. But this wonderful solution is rather problematic, specifically for Cabbage cultivation. Cabbage is a short duration crop so the nutrient availability must be easy and swift for its cultivation (Chatterjee, 2010).

Vermicompost is probably the most suited organic manure in this regard. Vermicompost is the end product of organic waste degradation through the interactions between earthworm and microorganisms (Arancon et al., 2007) and the process is called vermicomposting. Vermicomposting speeds-up the decomposition rates of organic matter and alters the physical and chemical properties of the material. It also reduces the C:N ratio, resulting in a rapid humidification process in which the unstable organic matter is completely oxidized and stabilized. Benefits of applying vermicompost include high levels of nutrients; low levels of contaminants (Atiyeh et al., 2000; Garg et al., 2006; Anon, 2009) and increased surface area for colonization by microorganisms (Arancon et al., 2005) and most importantly, high level of rapidly available nutrients, likenitrates and phosphates as well as such as exchangeable calcium and soluble potassium. The accumulating evidence shows that vermicompost has capability of influencing growth and productivity of short duration plants (Rasool et al., 2008).

Even though vermicompost has a faster nutrient release rate than most other organic manures, but it is still slowed very slow in comparison with chemical fertilizers. Organic soil conditioners, such as- Biochar, can assist organic manures in this. Biochar is a carbon-rich material obtained from thermo-chemical conversion (slow, intermediate, and fast pyrolysis or gasification) of biomass in an oxygen-limited environment. It can be produced from a range of feedstock, including forest and agriculture residues, such as straw, nut shells, rice hulls, wood chips/pellets, tree bark, and switch grass (Sohi et al., 2009). Biochar has been described as a possible tool for soil fertility improvement, potential toxic element adsorption, and climate change mitigation (Ennis et al., 2012, Malghani et al., 2013 and Stewart et al., 2013). Biochar application to soil can; improve soil physical and chemical properties (Mukherjee and Lal, 2013 and Sohi et al., 2010), enhance plant nutrient availability and correlated growth and yield (Biederman and Stanley, 2013 and Jeffery et al., 2011).

Considering the above fact, the present study was to investigate the efficacy of vermicompost and biochar on agronomic characteristics, yield performance and economic viability of green cabbage production in Bangladesh.

\section{Materials and Methods}

\subsection{Experimental design and layout}

The field experiment was carried out at the Horticultural farm of Sher-e-Bangla Agricultural University, Dhaka, Bangladesh during the period from October 2017 to March 2018. The variety, Atlas-70 of green cabbage was selected for the experiment. It was selected due to its better performance in previous experiments conducted in Sher-e-Bangla Agricultural University. The two-factor field experiment was laid out in a Randomized Complete Block Design (RCBD) with three replications. The factors were- levels of biochar $\left(\mathrm{B}_{0} \Rightarrow 0 \mathrm{t} / \mathrm{ha}\right.$ (Control); $\mathrm{B}_{1} \Rightarrow 2.10 \mathrm{t} / \mathrm{ha} ; \mathrm{B}_{2} \Rightarrow 6.20 \mathrm{t} / \mathrm{ha}$ and $\left.\mathrm{B}_{3} \Rightarrow 10.30 \mathrm{t} / \mathrm{ha}\right)$ and levels of vermicompost $\left(\mathrm{Vc}_{0} \Rightarrow 0 \mathrm{t} / \mathrm{ha}\right.$ (Control); $\mathrm{Vc}_{1} \Rightarrow 4.1 \mathrm{t} / \mathrm{ha} ; \mathrm{Vc}_{2} \Rightarrow 8.20 \mathrm{t} / \mathrm{ha}$ ). The area of the experimental field was divided into three equal blocks, followed by further division of blocks into 12 plots. Size of each plot is $1.8 \mathrm{~m} \times 1.35 \mathrm{~m}$. The distance between blocks and plots were $0.5 \mathrm{~m}$ and $0.25 \mathrm{~m}$ respectively.

\subsection{Plant Production}

A well-drained $3 \mathrm{~m} \times 1 \mathrm{~m}$ raised bed with sandy loam soil was prepared for growing seedlings. The soil was loose and friable and $5 \mathrm{~kg}$ cow dung was added in it. $10 \mathrm{~g}$ of seeds were sown. Meanwhile, the experiment site was harrowed, ploughed and cross-ploughed several times. The individual plots were made by making ridges $(20 \mathrm{~cm}$ high) around each plot. Different rates of biochar and vermicompost were incorporated into the plots. Healthy and uniform sized 30 days old seedlings were transplanted by maintaining a spacing of $45 \mathrm{~cm} \times 60 \mathrm{~cm}$. Intercultural operations like- gap filling, weeding and irrigation (light over-head irrigation) were carried out at 
regular interval. The crop was protected from the attack of insect-pest by spraying Melathion $45 \mathrm{EC}$ at the rate of $2 \mathrm{ml} / \mathrm{L}$ water.

Harvesting of cabbage was not possible on a particular date because of uniform head initiation in plants. Manual harvesting of compact marketable heads was done carefully.

\subsection{Statistical Procedure}

Observations were made on agronomic parameters, like- plant height $(\mathrm{cm})$, number of leaves plant ${ }^{-1}$, leaf length $(\mathrm{cm})$, leaf breadth $(\mathrm{cm})$ and spread of plant $(\mathrm{cm})$. Yield parameters, like- thickness of head $(\mathrm{cm})$, diameter of head $(\mathrm{cm})$, fresh weight $(\mathrm{g})$, dry matter content $(\%)$ and Total yield $(\mathrm{t} / \mathrm{ha})$ were recorded.

The data was statistically analyzed and Analysis of Variance (ANOVA) was carried out by using the MSTAT-C computer package program and the means were compared by the Least Significant Difference Test (LSD) at 5\% level of probability.

\subsection{Economic analysis}

The procedure of economic analysis was done in standard procedure (Alam et al., 1989). All the material and non-material input cost, interest on fixed capital of land and miscellaneous cost were considered for calculating the total cost of production. After that, gross return was calculated on the basis of mature cabbage head sale. The price of cabbage was assumed to be Tk. $15 / \mathrm{kg}$ basis of current market value of Kawran Bazar, Dhaka at the time of harvesting. Finally, net return was calculated by deducting the total production cost from gross income for each treatment combination.

The economic indicator, benefit cost ratio (BCR) was calculated by the following formula for each treatment combination.

$$
\text { Benefit cost ratio }(\mathrm{BCR})=\frac{\text { Gross income per hectare }}{\text { Total cost of production per hectare }}
$$

\section{Results and Discussion}

The study shows that different combination of biochar and vermicompost in the growing media has significant effect on both agronomic characteristics as well as yield of Green Cabbage. As expected, the lowest results were found in control for all agronomic characters (Table 1). Highest number of leaves per plant (17.60), plant height $(37.60 \mathrm{~cm})$, leaf breadth $(20.67 \mathrm{~cm})$, leaf length $(32.13 \mathrm{~cm})$, and plant spread $(58.93 \mathrm{~cm})$ was found in $\mathrm{B}_{3} \mathrm{Vc}_{2}$ which contained the highest amount of biochar and vermicompost (Table 1).

This scenario is somewhat changed in case of Yield parameters (Table 2). The poorest performance was recorded for control $\left(\mathrm{B}_{0} \mathrm{Vc}_{0}\right)$ just like the growth parameters. The best performances in thickness of head (10.29 $\mathrm{cm})$, diameter of head $(16.66 \mathrm{~cm})$, dry matter of cabbage $(14.93 \%)$, weight of cabbage head plant ${ }^{-1}(1370.00 \mathrm{~g})$ and yield of cabbage $\left(52.75 \mathrm{tha}^{-1}\right)$ were observed for $\mathrm{B}_{2} \mathrm{Vc}_{2}$.

The results also show that, terms of both agronomic characters (Table 1) and Yield parameters (Table 2), the performance of highest level of biochar $\left(\mathrm{B}_{2}\right)$ without vermicompost $\left(\mathrm{Vc}_{0}\right)$ was actually better than the performances of highest level of vermicompost $\left(\mathrm{Vc}_{2}\right)$ without any biochar application $\left(\mathrm{B}_{0}\right)$.

Table 1. Effect of biochar and vermicompost on different agronomic characteristics of Green Cabbage.

\begin{tabular}{llllll}
\hline Treatments & $\begin{array}{l}\text { Number of } \\
\text { leaves plant }\end{array}$ & $\begin{array}{l}\text { Plant height } \\
(\mathbf{c m})\end{array}$ & $\begin{array}{l}\text { Leaf breadth } \\
(\mathbf{c m})\end{array}$ & Leaf length (cm) & $\begin{array}{l}\text { Plant spread } \\
(\mathbf{c m})\end{array}$ \\
\hline $\mathrm{B}_{0} \mathrm{Vc}_{0}$ & $14.00 \mathrm{f}$ & $26.80 \mathrm{f}$ & $15.00 \mathrm{f}$ & $24.53 \mathrm{f}$ & $45.73 \mathrm{f}$ \\
$\mathrm{B}_{0} \mathrm{Vc}_{1}$ & $15.40 \mathrm{de}$ & $32.13 \mathrm{e}$ & $17.47 \mathrm{e}$ & $29.00 \mathrm{~d}$ & $53.27 \mathrm{de}$ \\
$\mathrm{B}_{0} \mathrm{Vc}_{2}$ & $15.60 \mathrm{de}$ & $33.20 \mathrm{de}$ & $17.93 \mathrm{de}$ & $29.47 \mathrm{~cd}$ & $53.73 \mathrm{~d}$ \\
$\mathrm{~B}_{1} \mathrm{Vc}_{0}$ & $15.20 \mathrm{e}$ & $31.53 \mathrm{e}$ & $17.33 \mathrm{e}$ & $28.07 \mathrm{e}$ & $52.00 \mathrm{e}$ \\
$\mathrm{B}_{1} \mathrm{Vc}_{1}$ & $15.93 \mathrm{~cd}$ & $34.40 \mathrm{~cd}$ & $18.47 \mathrm{~cd}$ & $29.80 \mathrm{bcd}$ & $53.93 \mathrm{~d}$ \\
$\mathrm{~B}_{1} \mathrm{Vc}_{2}$ & $16.33 \mathrm{c}$ & $35.13 \mathrm{bc}$ & $19.07 \mathrm{bc}$ & $30.07 \mathrm{bc}$ & $55.73 \mathrm{c}$ \\
$\mathrm{B}_{2} \mathrm{Vc}_{0}$ & $15.40 \mathrm{de}$ & $32.73 \mathrm{e}$ & $17.60 \mathrm{e}$ & $29.40 \mathrm{~cd}$ & $53.60 \mathrm{de}$ \\
$\mathrm{B}_{2} \mathrm{Vc}_{1}$ & $16.93 \mathrm{~b}$ & $35.80 \mathrm{bc}$ & $19.20 \mathrm{~b}$ & $30.47 \mathrm{~b}$ & $56.67 \mathrm{bc}$ \\
$\mathrm{B}_{2} \mathrm{Vc}_{2}$ & $17.00 \mathrm{~b}$ & $36.60 \mathrm{ab}$ & $20.50 \mathrm{a}$ & $31.40 \mathrm{a}$ & $58.27 \mathrm{ab}$ \\
$\mathrm{B}_{3} \mathrm{Vc}_{0}$ & $16.27 \mathrm{c}$ & $35.07 \mathrm{bc}$ & $18.53 \mathrm{~cd}$ & $30.07 \mathrm{bc}$ & $55.47 \mathrm{c}$ \\
$\mathrm{B}_{3} \mathrm{Vc}_{1}$ & $16.47 \mathrm{bc}$ & $36.27 \mathrm{ab}$ & $19.67 \mathrm{~b}$ & $30.47 \mathrm{~b}$ & $56.80 \mathrm{bc}$ \\
$\mathrm{B}_{3} \mathrm{Vc}_{2}$ & $17.60 \mathrm{a}$ & $37.60 \mathrm{a}$ & $20.67 \mathrm{a}$ & $32.13 \mathrm{a}$ & $58.93 \mathrm{a}$ \\
$\mathrm{LSD}$ & 1.557 & 0.6034 & 0.8399 & 1.526 \\
$\mathrm{CV}_{0}(\%)$ & 0.5461 & 6.68 & 9.27 & 5.25 & 5.36 \\
\hline
\end{tabular}

Here, $\mathrm{B}_{0} \Rightarrow 0 \mathrm{t} / \mathrm{ha} ; \mathrm{B}_{1} \Rightarrow 2.10 \mathrm{t} / \mathrm{ha} ; \mathrm{B}_{2} \Rightarrow 6.20 \mathrm{t} / \mathrm{ha}$ and $\mathrm{B}_{3} \Rightarrow 10.30 \mathrm{t} / \mathrm{ha}, \mathrm{Vc}_{0} \Rightarrow 0$ t/ha; $\mathrm{Vc}_{1} \Rightarrow 4.1 \mathrm{t} / \mathrm{ha} ; \mathrm{Vc}_{2} \Rightarrow 8.20 \mathrm{t} / \mathrm{ha}$ 
Table 2. Effect of biochar and vermicompost on yield parameters of cabbage.

\begin{tabular}{llllll}
\hline Treatments & $\begin{array}{l}\text { Thickness of } \\
\text { head }(\mathbf{c m})\end{array}$ & $\begin{array}{l}\text { Diameter of } \\
\text { head }(\mathbf{c m})\end{array}$ & $\begin{array}{l}\text { \% Dry matter of } \\
\text { cabbage }(\mathbf{g})\end{array}$ & $\begin{array}{l}\text { Weight of cabbage } \\
\text { head plant }\end{array}$ & $\begin{array}{l}\text { Yield of cabbage }(\mathbf{t} \\
\left.\text { ha }^{-1}\right)\end{array}$ \\
\hline $\mathrm{B}_{0} \mathrm{Vc}_{0}$ & $8.50 \mathrm{~g}$ & $12.90 \mathrm{f}$ & $8.863 \mathrm{~h}$ & $939.50 \mathrm{j}$ & $15.80 \mathrm{j}$ \\
$\mathrm{B}_{0} \mathrm{Vc}_{1}$ & $9.42 \mathrm{e}$ & $13.94 \mathrm{e}$ & $10.35 \mathrm{f}$ & $1090.00 \mathrm{~h}$ & $32.37 \mathrm{i}$ \\
$\mathrm{B}_{0} \mathrm{Vc}_{2}$ & $9.71 \mathrm{~cd}$ & $14.89 \mathrm{~cd}$ & $10.96 \mathrm{e}$ & $1172.00 \mathrm{f}$ & $35.41 \mathrm{~g}$ \\
$\mathrm{~B}_{1} \mathrm{Vc}_{0}$ & $8.89 \mathrm{f}$ & $13.59 \mathrm{e}$ & $9.497 \mathrm{~g}$ & $1065.00 \mathrm{i}$ & $31.43 \mathrm{~h}$ \\
$\mathrm{~B}_{1} \mathrm{Vc}_{1}$ & $9.77 \mathrm{c}$ & $14.92 \mathrm{~cd}$ & $11.63 \mathrm{~d}$ & $1227.00 \mathrm{e}$ & $47.85 \mathrm{~d}$ \\
$\mathrm{~B}_{1} \mathrm{Vc}_{2}$ & $9.85 \mathrm{bc}$ & $15.06 \mathrm{~cd}$ & $12.16 \mathrm{~cd}$ & $1239.00 \mathrm{~d}$ & $47.89 \mathrm{~d}$ \\
$\mathrm{~B}_{2} \mathrm{Vc}_{0}$ & $9.53 \mathrm{de}$ & $14.72 \mathrm{~d}$ & $10.75 \mathrm{ef}$ & $1162.00 \mathrm{~g}$ & $43.06 \mathrm{f}$ \\
$\mathrm{B}_{2} \mathrm{Vc}_{1}$ & $9.91 \mathrm{bc}$ & $15.25 \mathrm{bc}$ & $12.51 \mathrm{c}$ & $1253.00 \mathrm{c}$ & $48.42 \mathrm{c}$ \\
$\mathrm{B}_{2} \mathrm{Vc}_{2}$ & $10.29 \mathrm{a}$ & $16.66 \mathrm{a}$ & $14.93 \mathrm{a}$ & $1370.00 \mathrm{a}$ & $52.75 \mathrm{a}$ \\
$\mathrm{B}_{3} \mathrm{Vc}_{0}$ & $9.80 \mathrm{bc}$ & $15.05 \mathrm{~cd}$ & $11.81 \mathrm{~d}$ & $1232.00 \mathrm{de}$ & $45.62 \mathrm{e}$ \\
$\mathrm{B}_{3} \mathrm{Vc}_{1}$ & $9.86 \mathrm{bc}$ & $15.08 \mathrm{~cd}$ & $12.20 \mathrm{~cd}$ & $1248.00 \mathrm{c}$ & $48.21 \mathrm{c}$ \\
$\mathrm{B}_{3} \mathrm{Vc}_{2}$ & $10.0 \mathrm{~b}$ & $15.51 \mathrm{~b}$ & $13.41 \mathrm{~b}$ & $1289.00 \mathrm{~b}$ & $49.74 \mathrm{~b}$ \\
$\mathrm{LSD}_{0.05}$ & 0.186 & 0.3748 & 0.5381 & 8.032 & 0.822 \\
$\mathrm{CV}_{2}(\%)$ & 6.40 & 5.85 & 7.45 & 12.19 & 12.19 \\
\hline
\end{tabular}

Here, $\mathrm{B}_{0} \Rightarrow 0 \mathrm{t} / \mathrm{ha} ; \mathrm{B}_{1} \Rightarrow 2.10 \mathrm{t} / \mathrm{ha} ; \mathrm{B}_{2} \Rightarrow 6.20 \mathrm{t} / \mathrm{ha}$ and $\mathrm{B}_{3} \Rightarrow 10.30 \mathrm{t} / \mathrm{ha}, \mathrm{Vc}_{0} \Rightarrow 0 \mathrm{t} / \mathrm{ha} ; \mathrm{Vc}_{1} \Rightarrow 4.1 \mathrm{t} / \mathrm{ha} ; \mathrm{Vc}_{2} \Rightarrow 8.20 \mathrm{t} / \mathrm{ha}$

It is well established that, physical, chemical and microbiological condition of growing media affect the agronomic performance of the grown crops (Tsiakaras et al., 2014). Growing media or substrates include all materials that can be used to grow plants. It is reported that a proper combination of different substrate enhanced the plant agronomic characteristics due to the optimal C/N ratios (Dumroese et al., 2011). In the present study, both biochar and vermicompost are able to influence the physical and chemical properties of growth media. Biochar being a carbon sequester, has several beneficial effects on soil properties, such as increased water holding capacity (Karhu et al., 2011), enhanced cation exchange capacity (CEC) as well as base saturation (BS) (Yuan and $\mathrm{Xu}, 2011$ ), In addition to this, vermicompost alters both nutritional and microbial status of media (Islam et al., 2019).

The composition of biochars and vermicompost in the growth media of the present study was selected arbitrarily and not optimized with respect to the needs of a Cabbage. The best yield performance $(52.75 \mathrm{t} / \mathrm{ha})$ was generated when soil was amended with highest level of vermicompost $\left(\mathrm{Vc}_{2}\right.$, at an $\left.8.20 \mathrm{t} / \mathrm{ha}\right)$ alone with second highest dose of biochar $\left(\mathrm{B}_{2}, 6.20 \mathrm{t} / \mathrm{ha}\right)$. These results can be explained with the effect of biochar on plant nutrition and the nature of the crop. Even though, biochar itself does not provide any nutrients in soil, but beneficial impact of it on water holding capacity and porosity, improve the plant uptake of nutrients (Lehmann and Joseph, 2009). The effect of this can be noted in case of the individual influence of biochar and vermicompost (Table 1 and Table 2). But availability of appropriate soil nutrients in the soil is very vital in the production of Cabbage. It has been found that cabbage needs nitrogen in the optimum amount, while excessive $\mathrm{N}$ may result in formation of loose heads and internal decay, inadequate $\mathrm{N}$ amount results in non-formation of heads. Cabbage demand for P increases considerably at head formation stage, whereas, K deficiency can cause marginal necrosis and retards head quality. However, excessive K may result in head split (Khan et al., 2002). The highest amount of biochar in the media $\left(\mathrm{B}_{3}, 10.30 \mathrm{t} / \mathrm{ha}\right)$ with $\mathrm{Vc}_{2}$ probably created an excessive availability of soil nitrogen and potassium, which ultimately lower the yield (49.74 t/ha).

In the light of these evidences, the results show that it is possible to grow green cabbage in biochar and vermicompost media even at field conditions and their combinations influence both growth and yields. Our study shows that, the effect of individual biochar and vermicompost are cumulative when applied together, but the appropriate combination must be formulated according to the need of plant.

In the economic analysis, the cost benefit ratio was calculated in the Bangladesh context and the unit was expressed as Bangladeshi currency (BDT). The highest net return (BDT 523598) with a benefit cost ratio 3.70 was found for the treatment combination of $\mathrm{B}_{1} \mathrm{Vc}_{1}\left(2 \mathrm{tha}^{-1}\right.$ biochar with $4 \mathrm{tha}^{-1}$ vermicompost), while the lowest net return (BDT 162968) obtained from $\mathrm{B}_{0} \mathrm{Vc}_{0}\left(0 \mathrm{t} \mathrm{ha}^{-1}\right.$ biochar with $0 \mathrm{t} \mathrm{ha}^{-1}$ vermicompost) (Figure 1 and Figure 2). 


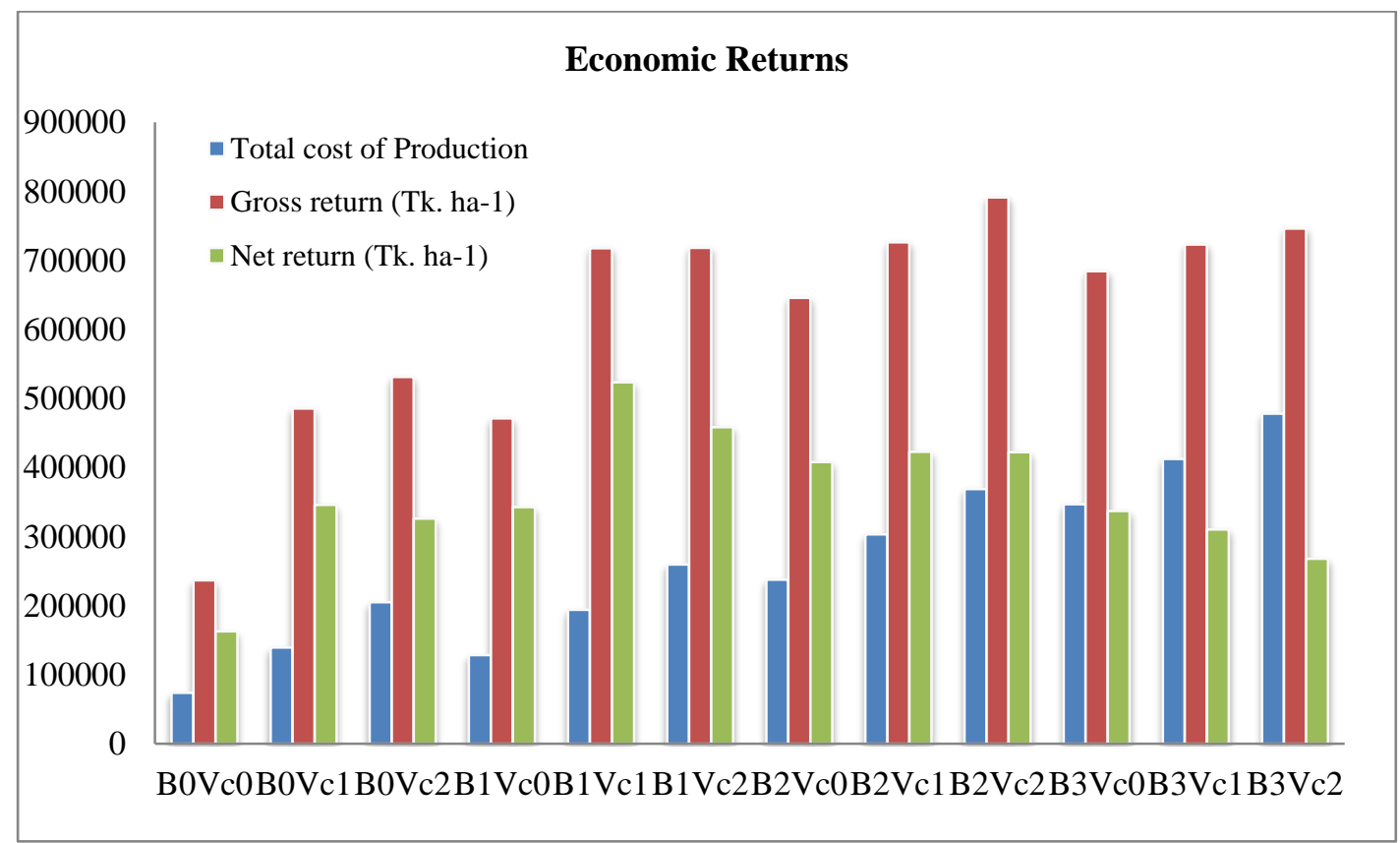

Here, $\mathrm{B}_{0} \Rightarrow 0 \mathrm{t} / \mathrm{ha} ; \mathrm{B}_{1} \Rightarrow 2.10 \mathrm{t} / \mathrm{ha} ; \mathrm{B}_{2} \Rightarrow 6.20 \mathrm{t} / \mathrm{ha}$ and $\mathrm{B}_{3} \Rightarrow 10.30 \mathrm{t} / \mathrm{ha}, \mathrm{Vc}_{0} \Rightarrow 0 \mathrm{t} / \mathrm{ha} ; \mathrm{Vc}_{1} \Rightarrow 4.1 \mathrm{t} / \mathrm{ha} ; \mathrm{Vc}_{2} \Rightarrow 8.20 \mathrm{t} / \mathrm{ha}$

\section{Figure 1. Economic analysis of cabbage production as influenced by biochar and vermicompost.}

Most cost-effective production procedure is the most useful information for farmers, particularly, small scale farmers. The incentives of farmers in food productions are cost effective production, better quality produce and increased net returns (Islam et al., 2021).

In this research, it is seeking the production of safe food and assist the rural producers in obtaining greater monetary returns, encouraging them to continue in the agricultural activity in sustainable way. Used as growing media, containing easily available and accessible local materials such as organic manure and biochar can be even with economic viable (Vendruscolo et al., 2019).

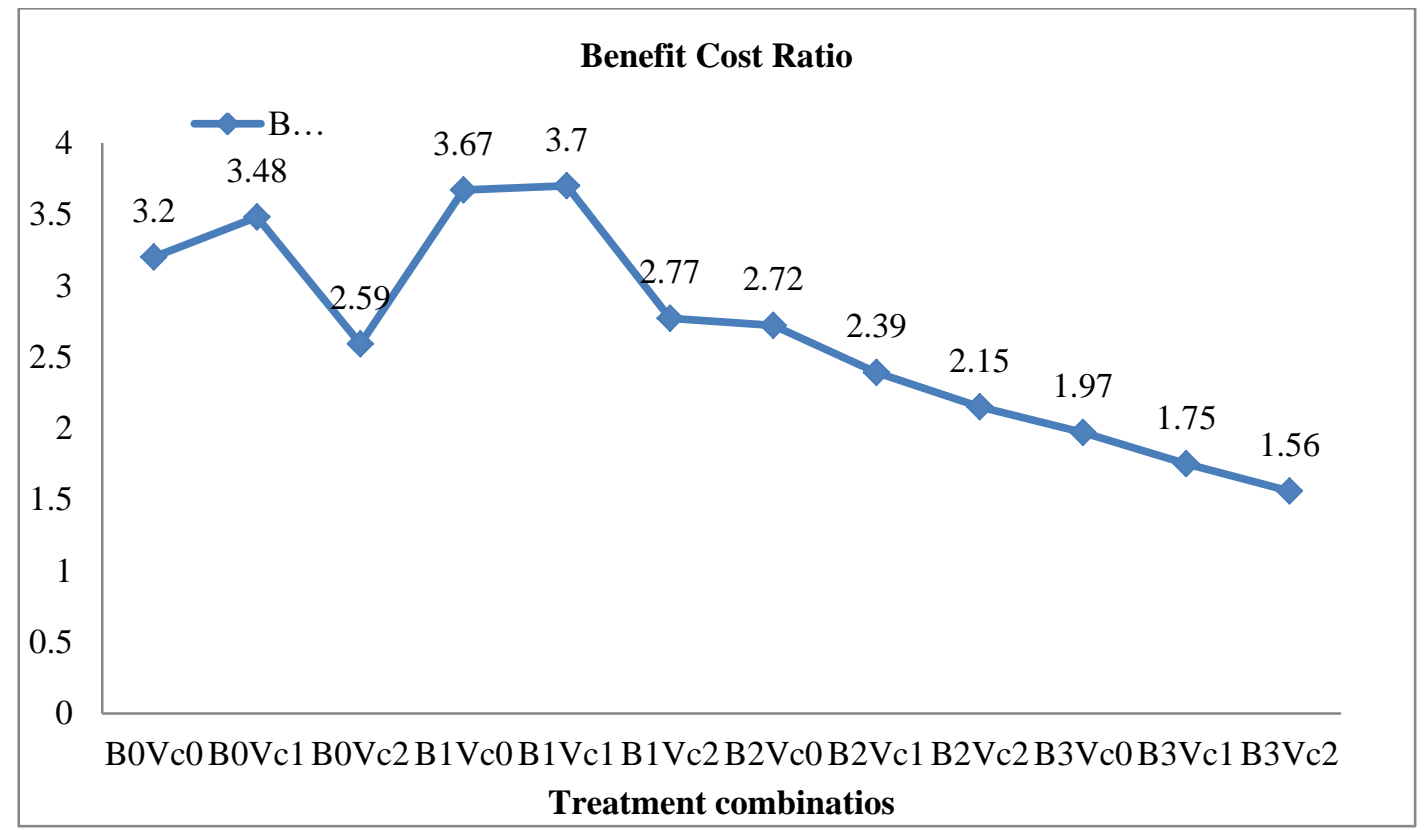

Here, $\mathrm{B}_{0} \Rightarrow 0 \mathrm{t} / \mathrm{ha} ; \mathrm{B}_{1} \Rightarrow 2.10 \mathrm{t} / \mathrm{ha} ; \mathrm{B}_{2} \Rightarrow 6.20 \mathrm{t} / \mathrm{ha}$ and $\mathrm{B}_{3} \Rightarrow 10.30 \mathrm{t} / \mathrm{ha}, \mathrm{Vc}_{0} \Rightarrow 0 \mathrm{t} / \mathrm{ha} ; \mathrm{Vc}_{1} \Rightarrow 4.1 \mathrm{t} / \mathrm{ha} ; \mathrm{Vc}_{2} \Rightarrow 8.20$ t/ha and $\mathrm{BCR}=$ Benefit Cost Ratio

Figure 2. Benefit cost ratio of cabbage production as influenced by biochar and vermicompost. 


\section{Conclusions}

Organic cultivation is the best way to produce nutrient rich, Green Cabbage when health and environment related safety is concerned. However, maintain the productivity of inorganic production is quite difficult in organic production. The farmers of Bangladesh cannot sustain cabbage production without economic viability. Incorporation of biochar and vermicompost in the growth medium of organic farming can improve the productivity and economic returns to the farmer alone with ensuring food safety. However, the most suitable combination of biochar and vermicompost to get the best results, demands considerable attention.

\section{Acknowledgements}

Authors hereby acknowledge Christian Commission for Development in Bangladesh (CCDB), 88, Senpara Parbata, Mirpur-10, Dhaka for providing Biochar needed for the experiment.

\section{Conflict of interest}

None to declare.

\section{References}

Adeniji OT, I Swai, MO Oluoch, R Tanyongana and A Aloyce, 2010. Evaluation of head yield and participatory selection of horticultural characters in cabbage (Brassica oleraceae var. Capitata L.). J. Plant Breed. Crop Sci., 2: 243-250.

Alam MAU, ME Hoque, UK Laily, MUS Khatun, MK Islam and SH Mollah, 2017. Growth and yield performance of cabbage under different combinations of vermicompost and fertilizers. Int. J. Adv. Res. Biol. Sci., 4: 79-86.

Anonymous, 2009. Earthworm vermicompost: a powerful crop nutrient over the conventional compost \& protective soil conditioner against the destructive chemical fertilizers for food safety and security. Journal of Agriculture and Environmental Science, 5: 01-55.

Arancon NQ, CA Edwards, P Biederman, JD Metzger and C Lucht, 2005. Effects of vermicomposts produced from cattle manure, food waste and paper waste on the growth and yield of peppers in the field. Pedobiologia, 49: 297-306.

Arancon NQ, CA Edwards, R Dick and L Dick, 2007.Vermicopost tea production and plant growth impact. Ohion state: Emmaus.

Atiyeh RM, S Subler, CA Edwards, G Bachman, JD Metzger and W Shuster, 2000. Effects of vermicomposts and composts on plant growth in horticultural container media and soil. PedoBiologia, 44: 579-590.

BBS, 2018. Year Book of Agricultural Statistics of Bangladesh. Bangladesh Bureau of Statistics, Planning Division, Ministry of Planning, Govt. of the Peoples Republic of Bangladesh, Dhaka. p. 108.

Biederman LA and HW Stanley, 2013. Biochar and its effects on plant productivity and nutrient cycling: a meta-analysis. GCB Bioenergy, 5: 202-214.

Caunii A, R Cuciureanu, A Zakar, E Tonea and C Giuchi, 2010. Chemical composition of common leafy vegetables. Studia Universitatis "Vasile Goldiş", Seria Ştiinţele Vieţii, 20: 45-48.

Chatterjee R, 2010. Physiological attributes of cabbage (Brassica oleracea) as influenced by different sources of nutrients under eastern Himalayan region. Res. J. Agric. Sci., 1: 318-321.

Dumroese RK, J Heiskanen, K Englund and A Tervahauta, 2011. Pelleted biochar: chemical and physical properties show potential use as substrate in container nurseries. Biomass Bioenergy, 35: 2018-2027.

Ennis CJ, AG Evans, M Islam, TK Ralebitso-Senior and E Senior, 2012. Biochar: carbon sequestration, land remediation, and impacts on soil microbiology. Crit. Rev. Environ. Sci. Technol., 42: 2311-2364.

Garg VK and P Kaushik, 2003.Vermicompostingof mixed solid textile mill sludge and cow dung with the epigeic earthworm Eisenia foetida. Bioresour. Technol., 90: 311-316.

Hasan MR and HMA Solaiman, 2012. Efficacy of organic and organic fertilizer on the growth of Brassica oleracea L. (Cabbage). Intl. J. Agri. Crop Sci., 4: 128-138.

Islam R, AHM Solaiman, MH Kabir, SMA Arefin, MOK Azad, MH Siddiqee, BW Alsanius and MT Naznin, 2021. Evaluation of lettuce growth, yield, and economic viability grown vertically on unutilized building wall in Dhaka City. Front. Sustain. Cities, 3: 582431.

Islam R, S Sultana, M Islam and C Mondal, 2019. Effect of aerated and non- aerated compost tea against some fungal phytopathogens. J. Bangladesh Agric. Uni., 17: 142-147.

Jeffery S, FGA Verheijen, Mvd Velde and AC Bastos, 2011. A quantitative review of the effects of biochar application to soils on crop productivity using metaanalysis. Agriculture, Ecosystems \& Environment, 144: 175-187. 
Karhu K, T Mattila, Bergstrom, Irina and K Regina, 2011. Biochar addition to agricultural soil increased CH4 uptake and water holding capacity-Results from a short-term pilot field study. Agriculture, Ecosystems and Environment, 140: 309-313.

Khan R, S Ahmed, S Khan, F Ahmed, A Singh and S Sharma, 2002. Composting of a crop residue through treatment with microorganisms and subsequent vermicomposting. Bioresour. Technol., 85: 107-111.

Kusznierewicz B, A Bartoszek, L Wolska, J Drzewiecki, S Gorinstein and J Namieśnik, 2008. Partial characterization of white cabbages (Brassica oleracea var. capitata $f$. alba) from different regions by glucosinolates, bioactive compounds, total antioxidant activities and proteins. LWT-Food Science and Technology, 41: 1-9.

Lehmann J and S Joseph, 2009. Biochar for environmental management. UK: Earthscan. p. 16-22.

Malghani S, G Gleixner and SE Trumbore, 2013. Chars produced by slow pyrolysis and hydrothermal carbonization vary in carbon sequestration potential and greenhouse gases emissions. Soil Biol. Biochem., 62: $137-146$.

Morem K, 2006. Response of cabbage (Brassica oleracea capitata var. Oleracea) Transplants to nitrogen, phosphorus and potassium. Pretoria: University of Pretoria.

Mukherjee A and R Lal, 2013. Biochar impacts on soil physical properties and greenhouse gas emissions. Agronomy, 3: 313-339.

Pavla B and R Pokluda, 2008. Influence of alternative organic fertilizers on the antioxidant capacity in head cabbage and cucumber. Horticultural Science (Prague), 36: 21-25.

Rasool A, TG Mousa and DT Rahim, 2008. Influence of vermicompost on soil chemical and physical properties in tomato (Lycopersicum esculentum) field. Afr. J. Biotechnol., 7: 2397- 2401.

Semuli KLH, 2005. Nitrogen Requirements for cabbage (Brassica oleracea capitata) transplants and crop response to spacing and nitrogen top-dressing. Pretoria: University of Pretoria.

Sinha RK, D Valani, K Chauhan, and S Agarwal, 2010. Embarking on a second green revolution for sustainable agriculture by vermiculture biotechnology using earthworms: Reviving the dreams of Sir Charles Darwin. J. Agric. Biotech. Sustain. Dev., 2: 113-128.

Sohi SP, E Krull, E Lopez-Capel and R Bol, 2009. A review of biochar and its use and function in soil. Adv. Agron., 105: 47-82.

Sohi SP, E Krull, E Lopez-Capel and R Bol, 2010. A review of biochar and its use and function in soil. Adv. Agron., 105: 47-82.

Stewart CE, J Zheng, J Botte and MF Cotrufo, 2013. Cogenerated fast pyrolysis biochar mitigates green-house gas emissions and increases carbon sequestration in temperate soils. GCB Bioenergy, 5: 153-164.

Tindall M, 2000. Mineral and organic fertilizing in cabbage. Residual effect for commercial cultivation on yield and quality performance with organic farming. Hort. Bras., 6: 15-20.

Tsiakaras G, A Spyridon, K Petropoulos and EM Khah, 2014. Effect of GA3 and nitrogen on yield and marketability of lettuce (Lactuca sativa L.). Aust. J. Crop Sci., 8: 127-132.

Vendruscolo EP, RAH Alcântara, SR Correia, PR Oliveira, CLF Cardoso and A Seleguini, 2019. Economic analysis of crisp lettuce production in different planting spacing and soil cover. Adv. Hortic. Sci., 33: 449455.

Yuan JH and RK Xu, 2011. The amelioration effects of low temperature biochar generated from nine crop residues on an acidic Ultisol. Soil Use Manag., 27: 110-115. 